\title{
TERMIN DO ZŁOŻENIA OŚWIADCZENIA O PRZYJĘCIU BA¿DŹ ODRZUCENIU SPADKU
}

\section{Uwagi wprowadzające}

Zgodnie z art. 1015 § 1 ustawy z dnia 23 kwietnia 1964 roku - Kodeks cywilny ${ }^{1}$ oświadczenie o przyjęciu bądź odrzuceniu spadku może być złożone w ciągu sześciu miesięcy od dnia, w którym spadkobierca dowiedział się o tytule swojego powołania. Natomiast, jak stanowi § 2 tego artykułu, brak oświadczenia spadkodawcy w powyższym terminie jest jednoznaczny z prostym przyjęciem spadku; jednakże, gdy spadkobierca jest osoba niemająca pełnej zdolności do czynności prawnych albo osoba, co do której istnieje podstawa do jej całkowitego ubezwłasnowolnienia, albo osoba prawna, brak oświadczenia spadkobiercy w tym terminie jest jednoznaczny z przyjęciem spadku z dobrodziejstwem inwentarza ${ }^{2}$.

W praktyce pojawia się wiele pytań związanych ze wskazanym wyżej sześciomiesięcznym terminem. Przede wszystkim rozważenia wymaga kwestia podstawowa, a mianowicie; jak należy liczyć bieg tego terminu? Czy w każdym przypadku początkowym dniem terminu będzie data otwarcia spadku, czyli data śmierci spadkodawcy, czy też w stosunku do poszczególnych kręgów spadkobierców ustawowych pierwszy dzień tego terminu może być różny? Jak należy traktować spadkobierców testamentowych w zakresie rozpatrywanego tu problemu?

$1 \quad$ Dz.U. Nr 16, poz. 93 z późn. zm.

2 Należy także zaznaczyć, iż zgodnie z art. 1023 kc. Skarb Państwa, jak też i gmina nie mogą odrzucić spadku, który im przypada z mocy ustawy. A contrario moga odrzucić spadek, do którego są powołani na mocy testamentu. Skarb Państwa i gmina nie składają oświadczenia o przyjęciu spadku, a spadek uważa się za przyjęty z dobrodziejstwem inwentarza, czyli z ograniczeniem odpowiedzialności za długi spadkowe pro viribus patrimonium. Zob. postanowienie Sądu Najwyższego z dnia 10 czerwca 1964 roku, III CR 81/64, OSN 1965, nr 3, poz. 47. Zob. także wyrok Sądu Najwyższego z dnia 26 lutego 1970 roku, II CR 388/69, OSNC 1970, nr 12, poz. 229 oraz LEX nr 1111, z którego treści, między innymi, wynika, iż: „Jeżeli jeden ze spadkobierców przyjał spadek z dobrodziejstwem inwentarza bez względu na to, czy nastapiło to wskutek odpowiedniego oświadczenia woli, czy też przez niezłożenie takiego oświadczenia przez osobę niemająca pełnej zdolności do czynności prawnych, uważa się, że spadkobiercy inni, posiadający pełną zdolność do czynności prawnych, którzy nie złożyli w ustawowym terminie żadnego oświadczenia w kwestii przyjęcia spadku, również przyjęli spadek z dobrodziejstwem inwentarza." 
Wypada też zastanowić się nad sytuacją, gdy spadkobiercy powołani do spadku na mocy testamentu odrzucą spadek - od kiedy wówczas rozpocznie swój bieg sześciomiesięczny termin do złożenia oświadczenia o przyjęciu bądź odrzuceniu spadku dla spadkobierców ustawowych oraz dla spadkobierców ustawowych, którzy jednocześnie byli spadkobiercami testamentowymi?

\section{Termin do złożenia oświadczenia o przyjęciu bądź odrzuceniu spadku w świetle judykatury}

Przy próbie rozstrzygnięcia wyżej wskazanych kwestii, a także i innych, związanych zwłaszcza z zagadnieniem początku biegu terminu do złożenia oświadczenia o przyjęciu bądź odrzuceniu spadku, bardzo pomocne są orzeczenia Sądu Najwyższego, wydane w odmiennym nieco stanie prawnym, które zachowują wiele na aktualności oraz w obecnym stanie prawnym, a zwłaszcza stwierdzenia zawarte w ich uzasadnieniach. Należy jednakże pamiętać, że orzeczenia Sądu Najwyższego nie są źródłem powszechnie obowiązującego prawa w Polsce, są wydawane w konkretnej sprawie, wiażą tylko w tej konkretnej sprawie, z uwagi jednak na autorytet Sądu Najwyższego dokonywana przez niego wykładnia przepisów ${ }^{3}$, zwłaszcza jeśli jest jednolita, a także wywody zawarte w uzasadnieniach orzeczeń tegoż Sądu nie mogą pozostawać niezauważone przez praktyków oraz przez sądy niższych instancji.

Należy zaznaczyć, iż zgodnie z art. $61 \S 6$ ustawy z dnia 23 listopada 2002 roku o Sądzie Najwyższym ${ }^{4}$ uchwały pełnego składu Sądu Najwyższego, składu połączonych izb oraz składu całej izby z chwilą ich podjęcia uzyskują moc zasad prawnych. Natomiast w myśl art. 62 u.s.n., jeżeli jakikolwiek skład Sądu Najwyższego zamierza odstapić od zasady prawnej, przedstawia powstałe zagadnienie prawne do rozstrzygnięcia pełnemu składowi izby, zaś odstąpienie od zasady prawnej uchwalonej przez izbę, przez połączone izby albo przez pełny skład Sądu Najwyższego wymaga ponownego rozstrzygnięcia $\mathrm{w}$ drodze uchwały odpowiednio przez właściwą izbę, połączone izby lub pełny skład Sądu Najwyższego. Z kolei, gdy skład jednej izby zamierza odstapić od zasady prawnej uchwalonej przez inną izbę, rozstrzygnięcie następuje w drodze uchwały obu izb, izby mogą przedstawić zagadnienie prawne do rozpoznania również przez pełny skład Sądu Najwyższego. Trzeba jednak cały czas pamiętać, że obowiązująca w Polsce Konstytucja nie wymienia w art. 87 tak określonych „zasad prawa” jako źródeł prawa powszechnie obowiązującego w Polsce, a wyliczenie źródeł prawa w tym artykule jest wyliczeniem enumeratywnym.

W kontekście powyższych rozważań na szczególną uwagę zasługuje uchwała Sądu Najwyższego z dnia 15 stycznia 1991 roku, III CZP 75/90, która zosta-

Zob. szerzej na ten temat, np. A. Stelmachowski, Zarys teorii prawa cywilnego, Warszawa 1998, s. 285 i nast. Dz.U. Nr 240, poz. 2052 z późn. zm. 
ła podjęta w związku ze skierowanym przez Sąd Wojewódzki w Krakowie zagadnieniem prawnym do rozstrzygnięcia, a mianowicie: „Od jakiej daty należy liczyć bieg terminu do złożenia oświadczenia o przyjęciu lub odrzuceniu spadku (art. 1015 $\S 1$ kc.) w stosunku do spadkobiercy powołanego w testamencie, jak również spadkobierców ustawowych w przypadku testamentu nieważnego ze względu na brak formy prawem przewidzianej?” W odpowiedzi na to pytanie Sąd Najwyższy podją następująca uchwałę, z której jednoznacznie wynika, że: sześciomiesięczny termin do złożenia oświadczenia o przyjęciu lub odrzuceniu spadku z ustawy rozpoczyna się - zarówno dla spadkobiercy ustawowego powołanego w testamencie do spadku, jak i dla pozostałych spadkobierców ustawowych $-\mathrm{z}$ dniem, w którym dowiedzieli się oni z właściwego źródła o tym, że testament z uwagi na niezachowanie prawem przepisanej formy jest nieważny ${ }^{5}$. Nadto, w uzasadnieniu powyższej uchwały Sąd Najwyższy zaznaczył, iż nabycie spadku jest uzależnione przede wszystkim od woli spadkobiercy ${ }^{6}$. Do uzewnętrznienia woli w tym przedmiocie prawodawca zakreślił spadkobiercy termin sześciu miesięcy liczony od chwili, w której dany spadkobierca dowiedział się o tytule swojego powołania do dziedziczenia. Oświadczenie złożone ustnie lub na piśmie z podpisem urzędowo poświadczonym w tym terminie przed sądem lub państwowym biurem notarialnym (obecnie przed notariuszem w prowadzonej przez niego kancelarii notarialnej, a w wyjątkowych przypadkach i poza kancelarią) ${ }^{7}$ oznacza definitywne, zgodne z wolą spadkobiercy nabycie spadku. Należy podkreślić, że niezłożenie przed upływem terminu określonego w $\S 1$ art. 1015 kc. oświadczenia jest zwykle traktowane jako jednoznaczne z prostym przyjęciem spadku, zgodnie z art. $1015 \S 2$ zd. 1 kc. Sąd Najwyższy w uzasadnieniu wyżej powołanej uchwały podkreślił również, że istotne znaczenie ma wyjaśnienie,

5 Zob. wyrok Sądu Najwyższego z dnia 15 stycznia 1991 roku, III CZP 75/90, OSNC 1991, nr 5-6, poz. 68 oraz LEX nr 3627, zawierający opisaną powyżej uchwałę Sądu Najwyższego.

6 Spadkobierca poza przyjęciem spadku wprost (bez ograniczenia za długi spadkowe), może przyjąć spadek z dobrodziejstwem inwentarza (z ograniczeniem odpowiedzialności za długi spadkowe do wartości ustalonego w spisie inwentarza stanu czynnego spadku) bądź też spadek odrzucić i wówczas traktowany jest jakby nie dożył otwarcia spadku.

7 Zob. postanowienie Sądu Najwyższego z dnia 10 listopada 2006 roku, I CSK 228/06, OSNC 2007, nr 7-8, poz. 123, „Rejencie” 2007, nr 4, s. 207 oraz LEX nr 234787. Z treści powołanego orzeczenia wynika, iż: „Złożenie oświadczenia o przyjęciu lub odrzuceniu spadku przed notariuszem wymaga formy aktu notarialnego". Nadto warto przedstawić w tym miejscu fragment uzasadnienia prawnego tego orzeczenia, w którym Sąd Najwyższy stwierdził, iż na podstawie wyliczenia zawartego w art. 79 w zw. z art. 92 ustawy z dnia 14 lutego 1991 roku Prawo o notariacie można wywieść, że oświadczenie woli przed notariuszem może zostać złożone jedynie ustnie, zwłaszcza z uwagi na treść art. $92 \S 1$ pkt 5 pr.not. W obowiązującym stanie prawnym nie sposób przyjąć, że oświadczenie woli składane przed notariuszem może przybrać inną formę niż forma aktu notarialnego, a złożenie oświadczenia „przed notariuszem” oznacza złożenie oświadczenia woli w jego obecności. Takim oświadczeniem woli spadkobiercy jest oświadczenie o przyjęciu lub odrzuceniu spadku, co w konsekwencji oznacza, że wola spadkobiercy co do przyjęcia lub odrzucenia spadku musi zostać uzewnętrzniona w obecności notariusza i utrwalona w postaci aktu notarialnego. Nie stanowi natomiast, zdaniem Sądu Najwyższego, takiego uzewnętrznienia woli sporządzenie przez spadkobiercę pisma zawierającego treść jego oświadczenia co do spadku i jedynie złożenie na nim podpisu w obecności notariusza, ponieważ wówczas notariusz poświadcza jedynie własnoręczność podpisu spadkobiercy, który został złożony w jego obecności przez oznaczoną osobę. Nadto, jak podkreślił Sąd Najwyższy, notariusz przy tego rodzaju poświadczeniu nie ma obowiązku zapoznawania się z treścią oświadczenia, jakie zawarte zostało w treści pisma. Nie można zatem uznać, że złożone w ten sposób oświadczenie woli zostaje złożone przed notariuszem, zgodnie z wymogami art. 1018 § 3 zdanie pierwsze kc. 
od jakiej chwili rozpoczyna się dla danego spadkobiercy bieg sześciomiesięcznego terminu do przyjęcia lub odrzucenia spadku. W myśl art. $1015 \S 1 \mathrm{kc}$. jest to dzień, w którym dany, konkretny spadkobierca dowiedział się o tytule swojego powołania do spadku'.

Ponadto, zgodnie z rozważaniami zawartymi w uzasadnieniu do tej uchwały, w poszczególnych sytuacjach początek terminu, czyli data, od której możliwe jest złożenie oświadczenia o przyjęciu bądź odrzuceniu spadku, może kształtować się odmiennie w stosunku do poszczególnych spadkobierców, nawet $\mathrm{z}$ tego samego kręgu uprawnionych do dziedziczenia po danym zmarłym9 ${ }^{9}$. Dla spadkobiercy ustawowego dzień ten jest jednak, jak zauważył Sąd Najwyższy, zwykle tożsamy z dniem dowiedzenia się o śmierci spadkodawcy, gdy już wówczas wiedział, że jest powołany do spadku po danej osobie z uwagi na łączące go ze spadkodawcą stosunki rodzinne, na których opiera się dziedziczenie ustawowe. Jeżeli spadkobierca miał świadomość istnienia innych osób, które wyłączają go od dziedziczenia z ustawy, to omawiany termin do złożenia oświadczenia o przyjęciu lub odrzuceniu spadku rozpocznie się później, to jest dopiero od dnia, w którym dany spadkobierca dowie się o uznaniu za niegodnego dziedziczenia spadkobiercy, który był powołany do dziedziczenia z mocy ustawy przed nim bądź też od dnia, w którym osoba mająca silniejsze od niego prawa spadkowe złożyła oświadczenie o odrzuceniu spadku. Zgodzić należy się również z tezą zawartą w uzasadnieniu do omawianej uchwały, iż silniejsze prawa do spadku, od spadkobierców powołanych do dziedziczenia $\mathrm{z}$ ustawy, mają spadkobiercy testamentowi jako powołani do spadku na podstawie woli testatora. Stąd, gdy osoba należąca do kręgu spadkobierców ustawowych wie, że spadkodawca powołał testamentem inną osobę, to sześciomiesięczny termin do przyjęcia przez niego z ustawy lub odrzucenia spadku rozpoczyna się dopiero od dnia, gdy dowiedział się, że spadkobierca testamentowy jest niegodny dziedziczenia, odrzucił spadek, albo że testament - np. ze względu na brak formy określonej w art. 949 kc. - jest nieważny ${ }^{10}$. Należy mieć także na uwadze, że jak podkreślił Sąd Najwyższy ${ }^{11}$, w grę tu może wchodzić jedynie informacja o nieważności testamentu, która pochodzi z miarodajnego źródła. Wystarcza, żeby o nieważności testamentu spadkobierca ustawowy został poinformowany - po otwarciu i ogłoszeniu testamentu - przez sąd spadku. Warto zaznaczyć, iż uprawnienia do otwierania i ogłaszania testamen-

8

Zob. i por. J. Pisuliński, Niektóre problemy związane z terminem do złożenia oświadczenia o przyjęciu lub odrzuceniu spadku, „Rejent” 1992, nr 6, s. 54 i nast. oraz E. Skowrońska-Bocian, Komentarz do kodeksu cywilnego. Księga czwarta. Spadki, wyd. 8, Warszawa 2007, s. 191-193. 9 Zob. zwłaszcza J. Ciszewski, Ustawowe i umowne ograniczenia odpowiedzialności osobistej, „Gdańskie Stulub odrzuceniu spadku. Forma oświadczenia i termin do jego złożenia, „Przegląd Sądowy” 2009, nr 11-12, s.71 i nast.

10 Zob. zwłaszcza uzasadnienie do wyroku Sądu Najwyższego z dnia 15 stycznia 1991 roku, III CZP 75/90, OSNC 1991, nr 5-6, poz. 68 oraz LEX nr 3627.

11 Zob. przyp. nr 10. 
tu przysługuje również notariuszom ${ }^{12}$, jednakże nie mają oni kompetencji do stwierdzania nieważności testamentu z uwagi na wystapienie okoliczności wymienionych w art. 945 kc. Od chwili uzyskania takiej informacji rozpoczyna się omawiany termin również dla osoby powołanej do spadku w nieważnym testamencie, jeżeli jest ona równocześnie spadkobiercą ustawowym po danym spadkodawcy.

Na aprobatę zasługuje również stwierdzenie Sądu Najwyższego zawarte w uzasadnieniu przedstawionej powyżej uchwały ${ }^{13}$, że spadkobiercy nie można przymuszać do złożenia oświadczenia o przyjęciu lub o odrzuceniu spadku. Wola złożenia ustnie do protokołu, wyrażona zwłaszcza w toku postępowania o stwierdzenie nabycia spadku, oświadczenia w tym przedmiocie, powinna być respektowana przez sąd spadku. Negatywne stanowisko sądu nie może tu szkodzić w jakikolwiek sposób prawom spadkobiercy. Za zachowany należy więc uznać termin określony w art. $1015 \S 1$ kc., jeżeli spadkobierca przed jego upływem zwrócił się do sądu o przyjęcie oświadczenia o przyjęciu bądź odrzuceniu spadku i zostało ono odebrane przez ten sąd po jego upływie. Odmowa przyjęcia przez sąd oświadczenia w tym przedmiocie, w takiej sytuacji, podlega kontroli instancyjnej. Nie jest też wyłączone domniemanie, iż odmowa przyjęcia od takiego spadkobiercy oświadczenia do protokołu rozprawy w sprawie o stwierdzenie nabycia spadku mogłaby wytworzyć także $\mathrm{u}$ innych spadkobierców ustawowych biorących udział w rozprawie błędne i mylne przekonanie, że składanie przez nich oświadczeń o przyjęciu lub odrzuceniu spadku byłoby zbędne, gdyż nie są oni powołani do spadku, albo że ich oświadczenia są spóźnione, gdyż sześciomiesięczny termin w stosunku do nich już upłynął. Złożenie po upływie terminu określonego w $\S 1$ art. 1015 kc. oświadczenia spadkowego nie byłoby zaś wyłączone, gdyby okoliczności sprawy usprawiedliwiały uznanie, że spadkobierca nie złożył we właściwym czasie żadnego oświadczenia pod wpływem błędu co do prawa lub groźby, o czym stanowi art. 1019 § 2 i zgodnie z art. 690 kpc. zostałoby to zatwierdzone przez sąd po przeprowadzeniu rozprawy ${ }^{14}$. Miarodajnym wówczas jest początek terminu wskazany w przepisach, do których odsyła art. 1019 kc., czyli w art. 88 kc. Tak więc w przypadku niezłożenia oświadczenia o przyję-

12 Zob. zwłaszcza H. Ciepła, Notarialne akty poświadczenia dziedziczenia, „Nowy Przegląd Notarialny” 2009, nr 4, s. 17 i nast.; K. Grzybczak, M. Szpunar, Notarialne poświadczenie dziedziczenia jako alternatywny sposób stwierdzenia prawa do dziedziczenia, „Rejent” 2006, nr 7-8, s. 44 i nast.; G. Bieniek, Notarialne poświadczenie dziedziczenia, „Rejent” 2008, nr 9, s. 9 i nast.; a także G. Bieniek, Czynności notarialne w prawie spadkowym, „Łódzki Biuletyn Notarialny' 2009, nr 1(12), s. 7 i nast.

13 Zob. przyp. nr 5.

14 Zob. wyrok Sądu Najwyższego z dnia 4 lipca 1986 roku, III CZP 36/86, OSNC 1987, nr 8, poz. 107 oraz LEX nr 3264, zawierający uchwałę Sądu Najwyższego o następującej treści: „Przepis o błędzie wywołanym podstępnie (art. 86 kc.) ma zastosowanie do oświadczeń o przyjęciu lub odrzuceniu spadku (art. 1019 § 1 kc.)”, która została podjęta w odpowiedzi na pytanie prawne: „Czy przepisy o błędzie wywołanym podstępnie (art. 86 kc.) mają zastosowanie do oświadczeń o przyjęciu lub odrzuceniu spadku (art. 1019 § 1 kc.)?". Zob. również postanowienie Sądu Najwyższego z dnia 30 czerwca 2005 roku, IV CK 799/04, OSNC 2006, nr 5, poz. 94 oraz LEX nr 159101, z którego treści, między innymi, wynika, iż: „Podstawę uchylenia się przez spadkobiercę od skutków prawnych niezłożenia $w$ terminie oświadczenia o przyjęciu lub odrzuceniu spadku może stanowić błąd prawnie doniosły (art. 1019 § 2 w zw. z art. 84 § 1 zdanie pierwsze i § 2 kc.)..." 
ciu bądź odrzuceniu spadku pod wpływem błędu uprawnienie to wygasa z upływem roku od jego wykrycia, zaś w przypadku groźby z upływem roku od chwili, kiedy stan obawy ustał ${ }^{15}$.

Warto także wskazać, że jeżeli chodzi o osoby małoletnie niemające zdolności do czynności prawnych, to na odrzucenie spadku, jak i na przyjęcie spadku wprost, którego dokonuje w ich imieniu przedstawiciel ustawowy w postaci rodzica posiadającego pełnię władzy rodzicielskiej lub opiekuna, jeśli rodzice nie żyją lub nie mają władzy rodzicielskiej - sąd opiekuńczy powinien wyrazić zgodę w trybie art. $101 \S 3$ k.r.o. ${ }^{16}$. Pojawia się wówczas pytanie, czy termin do złożenia stosownego oświadczenia zostanie zachowany, jeżeli już sam sąd opiekuńczy, którym jest sąd rejonowy wydział rodzinny i nieletnich, wydając zezwolenie na dokonanie czynności przekraczającej zakres zwykłego zarządu majątkiem małoletniego, wyda takie zezwolenie po upływie terminu do złożenia oświadczenia z art. $1015 \S 1$ kc. Wówczas należy zgodzić się z fragmentem powołanego powyżej uzasadnienia uchwały Sądu Najwyższego ${ }^{17}$, które jest bardzo pomocne w rozpatrywanej sytuacji. Należy zauważyć, że samo złożenie wniosku o wyrażenie zezwolenia przez sąd opiekuńczy przed upływem sześciomiesięcznego terminu na złożenie oświadczenia o przyjęciu spadku wprost lub o odrzuceniu spadku przez przedstawiciela ustawowego małoletniego jest wystarczające do zachowania terminu, ponieważ negatywne działanie sądu w postaci długotrwałego postępowania nie może szkodzić spadkobiercom, zwłaszcza małoletnim, przy których wymaganych jest tak wiele dodatkowych czynności w przypadku składania w ich imieniu oświadczenia o przyjęciu spadku wprost bądź oświadczenia o odrzuceniu spadku. Trzeba również wziąć pod uwagę postanowienia art. 45 ust. 1 Konstytucji, stanowiący, iż każdy ma prawo do sprawiedli-

Zob. zwłaszcza wyrok Sądu Najwyższego z dnia 15 stycznia 1991 roku, III CZP 75/90 i jego uzasadnienie, OSNC 1991, nr 5-6, poz. 68 oraz LEX nr 3627, zawierający opisaną powyżej uchwałę Sądu Najwyższego. Zob. postanowienie Sądu Najwyższego z dnia 25 czerwca 1996 roku, II CRN 214/95, opublikowane w Prok.i Pr.wkł. 1996, nr 11, poz. 40 oraz w Systemie Informacji Prawnej LEX pod nr 26273, z którego treści, między innymi, wynika, iż nabycie spadku przez osobę niemająca pełnej zdolności do czynności prawnych, a więc m.in. przez osobę małoletnią, wymienioną w art. 11 kc., z wyjątkiem sytuacji, gdy następuje ono na podstawie oświadczenia o przyjęciu spadku wprost, które jednakże wymaga zgody sądu opiekuńczego, udzielonej na podstawie art. $101 \S 3$ bądź art. 156 lub art. $178 \S 2$ k.r.o. - jest zawsze bezpłatnym przysporzeniem, którego rozmiar jest określony ustawowo przy dziedziczeniu ustawowym lub treścią testamentu przy dziedziczeniu testamentowym. Gdy długi spadku są równe wartości stanu czynnego spadku lub go przewyższają - wprawdzie do przysporzenia nie prowadzi, ale nie powoduje również żadnego uszczuplenia majątkowego. Dlatego w postępowaniu o stwierdzenie nabycia spadku, w którym małoletnie dziecko reprezentowane jest przez jedno z rodziców będące też spadkobierca, reguła jest, iż nie zachodzi między nimi kolizja interesów, która wykluczałaby w myśl art. $98 \S 3$ k.r.o. w związku z § 2 tego artykułu reprezentację dziecka przez tegoż rodzica. Jednakże wyjątkowo, gdy np. rodzic reprezentujący dziecko domaga się na swoją rzecz udziału w spadku ponad wynikający z treści testamentu albo podważa ważność testamentu sporządzonego na rzecz dziecka, działanie jego zmierza do uszczuplenia udziału w spadku przypadającego dziecku lub nawet do pozbawienia go tego udziału. Tak też działanie rodzica należy ocenić, gdy dochodzi on - obok dziecka - stwierdzenia dziedziczenia gospodarstwa rolnego wchodzącego w skład spadku na swoją rzecz, w okolicznościach nasuwających uzasadnione wątpliwości co do tego, czy spełnia warunki uprawniające go do tego dziedziczenia. Jeżeli więc wówczas dziecka nie może reprezentować drugie z rodziców, powinien je reprezentować kurator ustanowiony na podstawie art. 99 k.r.o. przez sąd opiekuńczy. 
wego i jawnego rozpatrzenia sprawy bez nieuzasadnionej zwłoki przez właściwy niezależny, bezstronny i niezawisły sąd. Jest to osobiste prawo człowieka do rzetelnej procedury sądowej, które uregulowane zostało również w art. 6 Europejskiej Konwencji o ochronie praw człowieka i podstawowych wolności z 4 listopada 1950 roku, której Rzeczpospolita Polska jest stroną.

$Z$ terminem do złożenia oświadczenia z art. $1015 \S 1 \mathrm{kc}$. wiążą się również i inne problemy ${ }^{18}$. Na pierwszy plan wyłania się zagadnienie, czy spadkobierca powinien wiedzieć, że nie istnieją osoby powołane do spadku przed nim? To znaczy czy spadkobierca powinien być pewien, że osoba uprawniona do dziedziczenia przed nim nie żyje, czy też złożyła skutecznie oświadczenie o odrzuceniu spadku i jest wówczas traktowana tak jakby nie dożyła otwarcia spadku ${ }^{19}$ ? Odpowiedź na te pytania wskaże, od którego momentu rozpocznie się bieg terminu do przyjęcia bądź odrzucenia spadku i oczywiście wpłynie w sposób istotny w większości przypadków na długość okresu pomiędzy śmiercią spadkodawcy a złożeniem oświadczenia.

\section{Kilka przykładów ilustrujących skutki prawne zachowania lub niezachowania terminu do złożenia oświadczenia o przyjęciu bądź odrzuceniu spadku}

Interesujący wydaje się następujący przypadek: zmarły pozostawał w separacji orzeczonej prawomocnym wyrokiem przez sąd okręgowy ze swoją małżonką ${ }^{20}$ i pozostawił po sobie jako spadkobierców ustawowych troje dzieci, z których jedno jest małoletnie. Pełnoletnie potomstwo zmarłego o jego zgonie zostało powiadomione tego samego dnia, co on nastąpił i od tego dnia rozpoczął się w stosunku do nich bieg sześciomiesięcznego terminu na złożenie oświadczenia, o którym stanowi art. 1012 kc. Natomiast małoletni zstępny spadkodawcy w chwili jego śmierci miał lat 8, a matka małoletniego, która pozostawała ze zmarłym w separacji sądowej, dowiedziała się o śmierci swojego małżonka, czyli o tytule powołania do spadku swojej małoletniej córki, dopiero po upływie dwóch miesięcy. Po uzyskaniu informacji od notariusza, przed którym chciała złożyć oświadczenie o odrzuceniu spadku w imieniu małoletniej córki, dowiedziała się, że musi najpierw wystapić do sądu opiekuńczego celem uzyskania zezwolenia na dokonanie czynności przekraczającej zakres zwykłego zarządu majątkiem małoletniego dziecka, pozostającego pod jej władzą rodzicielską.

\footnotetext{
18 Por. J. Pisuliński, Niektóre problemy..., „Rejent” 1992, nr 6, s. 54 i nast.; J. Ciszewski, Ustawowe i umowne..., „Gdańskie Studia Prawnicze” 2003, nr 1, s. 17 i nast. oraz J. Misztal-Konecka, Warunki skuteczności oświadczenia..., „Przegląd Sądowy” 2009, nr 11-12, s.71 i nast.

19 Zob. J. Pisuliński, Niektóre problemy..., „Rejent” 1992, nr 6, s. 54 i nast.

20 Zob. art. $935^{1} \mathrm{kc}$. stanowiący, iż przepisów o powołaniu do dziedziczenia z ustawy nie stosuje się do małżonka spadkodawcy pozostającego w separacji, który został dodany do kc. przez ustawę z dnia 21 maja 1999 roku, Dz.U. Nr 52, poz. 532, zmiana weszła życie 16 grudnia 1999 roku.
} 
Wówczas możliwe są następujące dalsze scenariusze:

1) matka małoletniego nie występuje do sądu opiekuńczego w celu uzyskania zezwolenia w trybie art. $101 \S 3$ k.r.o. i upływa bezskutecznie sześciomiesięczny termin do złożenia oświadczenia o przyjęciu bądź odrzuceniu spadku, a dokładnie mija osiem miesięcy od dnia śmierci spadkodawcy, gdyż matka dowiedziała się po upływie dwóch miesięcy o tytule powołania swojej małoletniej córki do spadku po ojcu. W takim stanie faktycznym, zgodnie z art. 1015 § 2 kc., brak oświadczenia o przyjęciu bądź odrzuceniu spadku $\mathrm{w}$ terminie ustawowym jest jednoznaczny z przyjęciem spadku $\mathrm{z}$ dobrodziejstwem inwentarza;

2) matka małoletniego nie występuje do sądu rejonowego wydziału rodzinnego i nieletnich i w terminie sześciomiesięcznym od dowiedzenia się o tytule powołania swojej małoletniej córki do spadku po zmarłym ojcu, czyli w terminie, składa oświadczenie o odrzuceniu spadku. Niestety, oświadczenie o odrzuceniu spadku jest czynnością przekraczającą zakres zwykłego zarządu majątkiem małoletniego i konieczne jest zezwolenie sądu na skuteczne dokonanie takiej czynności, które - jak wskazuje sama nazwa „zezwolenie” powinno zostać uzyskane przed podjęciem czynności i nie jest możliwe uzyskanie „takiego zezwolenia” ex post, a tym samym nie nastapi konwalidacja oświadczenia poprzez późniejsze uzyskanie stosownego zezwolenia sądu na dokonanie tej czynności. Także w tej sytuacji, mimo w pełni zachowanego sześciomiesięcznego terminu do złożenia oświadczenia z art. 1012 kc., nie będzie ono wywoływało jakichkolwiek skutków prawnych - będzie nieważ$\mathrm{ne}^{21}$;

3) matka małoletniego od razu występuje do sądu opiekuńczego, uzyskuje zezwolenie na dokonanie czynności przekraczającej zakres zwykłego zarządu majątkiem jej małoletniej córki w postaci złożenia oświadczenia o odrzuceniu spadku przysługującego jej na podstawie ustawy po zmarłym ojcu, jednak nie podejmuje dalszych czynności, uważając, że w ten sposób odrzuciła już skutecznie w imieniu małoletniej córki spadek po ojcu. Tak jednak nie jest, ponieważ uzyskanie zezwolenia na dokonanie czynności nie oznacza dokonania tej czynności. Wówczas również upływa bezskutecznie termin do złożenia oświadczenia z art. 1012 kc. i następują skutki określone w art. $1015 \S 2$ kc.;

Zob. uchwałę całej Izby Cywilnej SN z dnia 24 czerwca 1961 roku 1CO 16/61, OSNCP 1963, nr 9, poz. 187, w której, między innymi, stwierdzono, iż czynność prawna dotycząca majątku małoletniego, dokonana przez przedstawiciela ustawowego bez uprzedniego zezwolenia „władzy opiekuńczej” (obecnie sądu opiekuńczego) wymaganego przez obecne przepisy w postaci art. 101 § 3 i 156 k.r.o., jest nieważna (art. 58 kc.) i nie może być konwalidowana. Por. H. Ciepła, B. Czech, T. Domińczyk, S. Kalus, K. Piasecki, M. Zychowicz, Kodeks rodzinny i opiekuńczy z komentarzem, Warszawa 2001, s. 572-578 i 588-594. 
4) po uzyskaniu zezwolenia sądu opiekuńczego na dokonanie czynności przekraczającej zakres zwykłego zarządu majątkiem małoletniego przedstawiciel ustawowy składa przed sądem lub przed notariuszem oświadczenie o odrzuceniu spadku, jednak dokonuje tego już po upływie sześciomiesięcznego terminu, który jest przewidziany w art. $1015 \S 1 \mathrm{kc}$. Pojawia się wówczas pytanie: czy taka czynność będzie wywoływała jakiekolwiek skutki prawne? Mając na uwadze stwierdzenia zawarte w powołanym wyżej uzasadnieniu uchwały Sądu Najwyższego z dnia 15 stycznia 1991 roku III CZP 75/90 oraz wcześniejsze rozważania, należy przyjąć, iż mimo upływu sześciomiesięcznego terminu, oświadczenie w tym przypadku jest złożone skutecznie. Działania sądu nie mogą przecież krzywdzić któregokolwiek ze spadkobierców, w tym zwłaszcza małoletnich ${ }^{22}$. Wątpliwości pojawiają się tylko w sytuacji, gdyby takie oświadczenie zostało złożone przed notariuszem; czy byłoby również skuteczne; czy też możemy przyjąć wyższość sądowej formy złożenia oświadczenia nad notarialną? Wydaje się, że obie formy, w których czynność może być dokonana, powinny wywierać takie same skutki prawne, mieć taką samą moc prawną, skoro możliwe jest złożenie oświadczenia alternatywnie w jednej albo w drugiej formie.

Zdaniem A. Oleszko sąd spadku nie jest uprawniony do zwracania się do notariusza ,w celu właściwego stwierdzenia złożenia oświadczenia” z art. $640 \S 1 \mathrm{kpc}$., gdyż to do sądu spadku należy ocena, czy oświadczenie zostało złożone w przewidzianej prawem formie notarialnej oraz czy jest ważne i skuteczne w rozumieniu przepisów prawa materialnego ${ }^{23}$;

5) matka małoletniego po otrzymaniu zezwolenia sądu rejonowego wydziału rodzinnego i nieletnich składa w terminie sześciu miesięcy oświadczenie w imieniu małoletniej córki o odrzuceniu spadku po ojcu. Termin zostaje zachowany. Nie ma żadnych wątpliwości. Oświadczenie złożone w tej sytuacji będzie wywoływało wszelkie skutki prawne, jakie z nim wiąże ustawodawca;

6) matka wystąiła do sądu opiekuńczego w celu uzyskania zezwolenia na dokonanie czynności przekraczającej zakres zwykłego zarządu majątkiem małoletniego, jednakże nastapiło to po upływie terminu przewidzianego w art. $1015 \S 1 \mathrm{kc}$. Wydaje się, że wówczas sąd rejonowy wydział rodzinny i nieletnich bada, czy oby termin na złożenie oświadczenia o przyjęciu bądź odrzuceniu spadku jeszcze nie upłynął, ponieważ zezwalając przedstawicielowi ustawowemu na dokonanie czynności przekraczającej zakres zwykłe- 
go zarządu w imieniu małoletniego, powinien sprawdzić, czy czynność taka może być w ogóle skutecznie dokonana zwłaszcza wówczas, jeżeli upłynął stosunkowo długi termin od dnia otwarcia spadku. Nie zezwalając na dokonanie czynności bądź oddalając wniosek o zezwolenie, sąd powinien wskazać przedstawicielowi ustawowemu małoletniego, że może powoływać się ewentualnie na art. $1019 \S 3$ kc., pozwalający spadkobiercy, który pod wpływem błędu lub groźby nie złożył żadnego oświadczenia w terminie sześciu miesięcy na uchylenie się od skutków prawnych niezachowania terminu. Wydaje się również, że sąd opiekuńczy może wydać zezwolenie na dokonane czynności, mimo upływu terminu do złożenia oświadczenia o przyjęciu bądź odrzuceniu spadku, czekając na dalsze rozstrzygnięcie sądu spadku, $\mathrm{w}$ trakcie postępowania o stwierdzenie nabycia spadku.

W momencie skutecznego złożenia przez matkę małoletniego dochodzi do dziedziczenia przez dalsze kręgi spadkobierców ustawowych, czyli w rozpatrywanej sytuacji przez żyjących rodziców zmarłego, którzy będą dziedziczyli, na podstawie art. $932 \S 3 \mathrm{kc}$., w częściach równych z uwagi, że spadkobiercy uprawnieni przed nim do dziedziczenia w myśl art. 1020 kc. zostali od niego wyłączeni i są traktowani tak jakby nie dożyli otwarcia spadku. Pojawia się jednak pytanie, z którym momentem rodzice spadkodawcy mogą skutecznie złożyć oświadczenie o przyjęciu bądź odrzuceniu spadku. Czy już w momencie powzięcia przez nich wiadomości o tym, że wszystkie dzieci zmarłego (bezdzietni kawalerowie) i przedstawiciel ustawowy małoletniej córki zamierzają odrzucić spadek, czy też dopiero z momentem dojścia przez nich do dziedziczenia po ich zmarłym synu, to znaczy z momentem złożenia skutecznych oświadczeń o odrzuceniu spadku przez wszystkich spadkobierców uprawnionych do dziedziczenia przed nimi, czyli przez wszystkie dzieci zmarłego, w tym przez małoletnią córkę?

Aby rozwiązać przedstawiony powyżej problem, należy postarać się udzielić odpowiedzi na pytanie, jaką rolę odgrywa czas przy składaniu oświadczeń o przyjęciu bądź odrzuceniu spadku i w jaki sposób okres sześciu miesięcy został zakreślony i wyznaczony przez ustawodawcę. Zgodnie z art. $1015 \S 1 \mathrm{kc}$. termin sześciu miesięcy jest liczony od dnia, w którym spadkodawca dowiedział się o tytule swojego powołania. Tak więc dowiedzenie się o tytule swojego powołania do spadku nadaje bieg terminowi sześciomiesięcznemu do złożenia oświadczenia o przyjęciu bądź odrzuceniu spadku.

W sytuacji, gdy brak jest widomości o tytule powołania do spadku, wskazany powyżej termin nie zaczyna w ogóle płynąć. Wydaje się więc, że jeżeli oświadczenie o przyjęciu bądź odrzuceniu spadku nie zostanie złożone w zakreślonym przez ustawodawcę terminie, nie będzie ono wywoływało skutków prawnych jaki ustawo- 
dawca wiąże ze złożeniem takiego oświadczenia, czyli nie będzie ono oświadczeniem z art. 1012 kc., z którym prawo spadkowe wiąże szereg następstw prawnych.

Trzeba jeszcze zwrócić uwagę na art. 1018 § 1 kc., zgodnie z którym oświadczenie o przyjęciu bądź odrzuceniu spadku złożone pod warunkiem lub z zastrzeżeniem terminu jest nieważne. Podkreśla to bardzo doniosłą rolę, jaką odgrywa element czasu przy składaniu oświadczenia spadkowego z art. $1012 \mathrm{kc}$. Warto także zaznaczyć, że dla nadania biegu terminowi do złożenia oświadczenia o przyjęciu bądź odrzuceniu spadku istotna, jeśli nie najważniejsza, jest świadomość okoliczności uzasadniających powołanie do spadku, a nie okoliczności prawdopodobnych czy też watpliwych.

Wracając do próby udzielenia odpowiedzi na postawione powyżej pytanie, należy wskazać, iż rodzice zmarłego będą mogli złożyć skutecznie oświadczenie o przyjęciu bądź odrzuceniu spadku dopiero gdy wszyscy spadkobiercy ustawowi silniej powołani od nich złożą stosowne oświadczenia w sześciomiesięcznych terminach, które mogą biec oddzielnie dla każdego z nich i zostaną oni o tym powiadomieni. Czyli, z chwilą gdy rodzice będą mieli pełną świadomość prawną, że są powołani do spadku po swoim zmarłym synu na podstawie ustawy. Oświadczenie, które nie byłoby złożone $\mathrm{w}$ trakcie sześciomiesięcznego terminu $\mathrm{z}$ art. $1015 \S 1 \mathrm{kc}$., to znaczy byłoby złożone przed jego rozpoczęciem, byłoby bezwzględnie nieważne, w sytuacji gdyby spadkobierca silniej powołany do spadku nie złożył jeszcze oświadczenia o odrzuceniu spadku. Skuteczność oświadczenia o przyjęciu bądź odrzuceniu spadku złożonego przez rodzica byłaby wówczas uzależniona od spełnienia warunku, jakim jest odrzucenie spadku przez dziecko spadkodawcy.

\section{Konkluzje}

Bieg terminu do złożenia oświadczenia o przyjęciu bądź odrzuceniu spadku może rozpocząć się najwcześniej w dniu, w którym zostały spełnione wszystkie warunki sine qua non powołania danego spadkobiercy do spadku. Gdyby spadkobierca złożył oświadczenie wcześniej, to w obiektywnej ocenie, nie byłby wówczas jeszcze powołany do dziedziczenia i nie mógłby skutecznie złożyć takiego oświadczenia, ponieważ nie rozpoczął jeszcze swojego biegu w stosunku do niego termin do złożenia oświadczenia o przyjęciu bądź odrzuceniu spadku.

W sytuacji gdy oświadczenie o przyjęciu bądź odrzuceniu spadku ma być złożone po osobie uznanej za zmarłą na mocy orzeczenia sądowego, termin do złożenia wskazanego powyżej oświadczenia rozpoczyna swój bieg dopiero w dniu uprawomocnienia się orzeczenia o uznaniu za zmarłego. Nie może on rozpoczą́ się wcześ- 
niej, nawet gdyby spadkobiercy znane były okoliczności uzasadniające jego późniejsze powołanie do spadku ${ }^{24}$.

Zgodnie z art. 1017 kc., jeżeli przed upływem terminu do złożenia oświadczenia o przyjęciu bądź odrzuceniu spadku spadkobierca zmarł, nie złożywszy takiego oświadczenia, oświadczenie o przyjęciu lub o odrzuceniu spadku może być złożone przez jego spadkobierców (transmitariuszy). Termin do złożenia tego oświadczenia nie może skończyć się wcześniej aniżeli termin do złożenia oświadczenia co do spadku po zmarłym spadkobiercy (transmitencie). Tak więc transmitariusze wstępują niejako w prawo transmitenta do złożenia oświadczenia o przyjęciu bądź odrzuceniu spadku.

Sześciomiesięczny termin na skutek śmierci transmitenta nie ulega przerwaniu, biegnie dalej w stosunku do spadkobierców transmitenta, z takim tylko zastrzeżeniem, że nie może się on skończyć przed upływem terminu do złożenia oświadczenia co do spadku po transmitencie. Ulega więc on stosownej modyfikacji w ten sposób, że zostaje odpowiednio przedłużony ${ }^{25}$. Z przepisu art. 1017 kc. nie wynika, iż rozpoczyna on swój bieg w tej sytuacji w związku ze śmiercią transmitenta od nowa ${ }^{26}$, płynie on niezależnie od tego, czy i kiedy transmitariusz dowiedział się o tytule powołania trensmitenta. Inaczej przedstawia się tylko sytuacja gdy transmitent zmarł przed dowiedzeniem się o tytule swojego powołania, czyli nie rozpoczął się w stosunku do niego bieg sześciomiesięcznego terminu do złożenia oświadczenia o przyjęciu bądź odrzuceniu spadku. Wówczas termin do złożenia oświadczenia po spadkodawcy transmitenta biegnie w stosunku do transmitariusza dopiero od momentu dowiedzenia się o tytule powołania transmitenta do spadku. Należy jednak pamiętać, że jeśli transmitariusz odrzucił spadek po transmitencie, to nie jest możliwe złożenie oświadczenia o przyjęciu bądź odrzuceniu spadku po spadkodawcy transmitenta, ponieważ w stosunku do transmitariusza termin ten w ogóle nie będzie liczony, gdyż w myśl art. 1020 kc. jest on traktowany tak, jakby nie dożył otwarcia spadku po transmitencie ${ }^{27}$.

Prawo wiąże szereg poważnych konsekwencji ze złożeniem przez spadkobiercę oświadczenia o przyjęciu bądź odrzuceniu spadku, oczywiście pod warunkiem,

Zob. J. Pisuliński, Niektóre problemy..., „Rejent” 1992, nr 6, s. 54 i nast.

Transmitariusz ma w zasadzie tylko dwie możliwości: 1) może odrzucić spadek po pierwszym spadkodawcy, przyjąć spadek po transmitencie lub 2) może przyjąć oba spadki, gdyż jeżeli tranmitariusz odrzuciłby spadek po transmitencie, jego oświadczenie o przyjęciu spadku po pierwszym spadkodawcy trzeba by było uznać za bezskuteczne, ponieważ traktowany jest na podstawie art. 1020 kc. jakby nie dożył otwarcia spadku po transmitencie, a uprawnienie transmitariusza do przyjęcia lub odrzucenia spadku jest uzależnione od nabycia spadku i to w sposób definitywny po transmitencie. Zob. i por. J. Pisuliński, Niektóre problemy..., „Rejent” 1992, nr 6, s. 54 i nast. oraz E. Skowrońska-Bocian, Komentarz do kodeksu cywilnego. Księga czwarta. Spadki, wyd. 8, Warszawa 2007, s. 193-194.

26 Zob. A. Kunicki, Odrzucenie spadku przez transmitariusza, NP 1963, nr 12, s. 1356.

27 Zob. i por. E. Skowrońska-Bocian, Komentarz do kodeksu cywilnego. Księga czwarta. Spadki, wyd. 8, Warszawa 2007, s. 193-194 oraz K. Matuszczyk, Kilka uwag o transmisji spadku, „Palestra” 2006, nr 11-12, s. 97 i nast. 
że jest ono złożone w terminie zakreślonym przez art. $1015 \S 1$ kc. Przede wszystkim należy zaznaczyć, że wskazany sześciomiesięczny termin jest terminem zawitym prawa materialnego. Oznacza to, że oświadczenie spadkobiercy złożone po jego upływie nie będzie wywoływało jakichkolwiek skutków prawnych - będzie bezskuteczne. Dlatego tak ważne jest prawidłowe ustalenie jego początkowego dnia, który może być różny w stosunku do poszczególnych spadkobierców, gdyż jest on liczony od chwili, w której spadkobierca dowiedział się o tytule swojego powołania do spadku.

Termin nie może się rozpoczać w stosunku do spadkobierców, jeżeli nie dojdzie do otwarcia spadku.

Jeżeli zaś chodzi o spadkobierców uprawnionych do dziedziczenia w dalszej kolejności, to rozpoczyna on swój bieg gdy spadkobierca dowie się, że spadkobierca silniej powołany do spadku nie chce lub nie może dziedziczyć. W tej sytuacji termin na złożenie oświadczenia o przyjęciu bądź odrzuceniu spadku wobec spadkobiercy powołanego do spadku w dalszej kolejności zacząć się może najwcześniej dopiero od momentu spełnienia się warunków wyłączających od dziedziczenia spadkobierców powołanych do dziedziczenia w pierwszej kolejności.

Reasumując, aby oświadczenie o przyjęciu bądź odrzuceniu spadku było skuteczne, należy złożyć je w terminie wskazanym przez art. $1015 \S 1 \mathrm{kc}$., inaczej nie będzie ono wywierało zamierzonych przez spadkobiercę skutków prawnych.

Tak więc element czasu jest tu niezmiernie ważny i istotny, gdyż w sumie od niego zależy, przy spełnieniu pozostałych przesłanek ustawowych, możliwość efektywnego prawnie złożenia oświadczenia o przyjęciu bądź odrzuceniu spadku.

Powyższe rozważania miały na celu wskazanie tylko niektórych problemów związanych z terminem wskazanym w art. $1015 \S 1 \mathrm{kc}$., zwłaszcza ze sposobem ustalenia początku jego biegu. 


\title{
THE PROPER TIME FRAME WHICH IS APPLIED WHILE MAKING A STATEMENT OF ACCEPTING OR DECLINING AN INHERITANCE
}

\author{
SUMMARY
}

The article focuses on the proper timeframe which is applied while making a statement of accepting or declining an inheritance. Using particular examples the author illustrates how to count this amount of time in accordance to specific successors in various situations. It states that an heir is eligible to decide whether to accept or reject an inheritance within six-months starting from the moment of learning about the right to inherit. The article emphasises that the setting an actual date can be quite unclear due to the fact that a person can become aware of the possibility to succeed in different time, especially when it concerns the successors who are eligible to inherit in the further places. Stating the exact starting and ending date of this six-month period is of crucial importance as it results in momentous legal consequences. In order to have the right legal effect the statement considering the decision about inheritance must be handed in within six months what results from article $1015 \S 1$ of civil code. 